\title{
Neil Aggett: A man of the people
}

[ B O O K R E VIE W ]

Naidoo, Beverley (2012) Death of an

idealist: In search of Neil Aggett.

Johannesburg: Jonathan Ball.

ISBN 978-1-86842-520-4 pbk. Pages xix + 475
John Reynolds ${ }^{1}$

Neil Aggett Labour

Studies Unit,

Rhodes University,

Grahamstown

\section{Beverley Naidoo's Death of an idealist: In search of Neil}

Aggett is an extraordinary achievement. She brings to life the complex dynamics that shaped this remarkable South African, and gives us a rich portrait not only of him as a multi-faceted and changing human being, but also of the social and political environment in which his short life was lived. She evokes the time in which Dr Neil Hudson Aggett lived in all its complexity, sketching vividly not only the horrors of the apartheid system and its security apparatuses, but also the complex socialisation of people living within that system. In her richly detailed account of Neil's life, she illustrates the possibility of agency even in the most repressive of systems, and traces his development in dynamic interaction with his context.

Neil Aggett transcended his background to embody the ideal of a just, non-racial and non-sexist democratic South Africa. His privileged school education and his training as a medical doctor did not predetermine the trajectory of his life, but rather provided a context within which he engaged with ideas and with others around him. He opened himself to other people in a manner that changed him and them in unpredictable ways and that had social consequences beyond anything he could have imagined. He transcended the boundaries of race in

\footnotetext{
John Reynolds is the founding Head of the Neil Aggett Labour Studies Unit at Rhodes University
} 
the most racially divisive of times, and inspired strong bonds of respect and love while engaging honestly with the complexities of his and his fellow South Africans' lives.

However, his work in support of a democratic trade union movement drew the attention of the apartheid security police, in whose detention cells he died at the age of twenty-eight. At the time of his death, Neil was working as an unpaid trade union organiser for the African Food and Canning Workers Union by day and as a medical doctor at Baragwanath Hospital in Soweto by night. It is his remarkable journey from an early childhood in Kenya, to a privileged education in Grahamstown, to medical training in Cape Town, to trade unionist and medical doctor in Johannesburg, and to a brutal end in the security police cells at John Vorster Square, that is captured so vividly by Beverley Naidoo.

Neil Aggett completed his high school years at Kingswood College in Grahamstown in 1970, after which he studied medicine at the University of Cape Town, graduating in 1976. Beverley Naidoo takes us through his development into a young man who was taking an interest in politics, but "whose critical thinking remained deeply philosophical and introspective". It is during this time of intense introspection that Neil rejected organised religion and drifted away from his family. His internships in Mthatha General Hospital, and Tembisa Hospital in the East Rand exposed him to a broader range of social contexts and relationships, and contributed to the gradual development of his political consciousness.

Neil's move to Johannesburg occurred after the Soweto Uprising of 1976, and he was drawn into a network of relationships and activities through which he accelerated his development into the committed activist he was at the time of his detention by the apartheid security police. In his work as a medical doctor, both in hospital settings and as an Industrial Aid Society volunteer, Neil became acutely aware of the links between health and poor living and working conditions when treating his mainly working-class and poor black patients in apartheid era South Africa. This awareness of the root causes of workers' ill health inspired him to volunteer to organise workers into democratically accountable trade unions that could directly represent their social and economic interests. In his work as an organiser for the African Food and Canning Workers' Union, Neil Aggett demonstrated a deep commitment to workplace democracy and economic justice. At the time of his detention by the security police, he was Transvaal Secretary of his union.

Neil's life of selfless service and action against racial oppression and economic injustice touched many lives directly, and he was a well-loved and immensely respected figure amongst the trade union members with whom he lived, worked and shared his life. 
His death in detention on 5 February 1982, after enduring lengthy and brutal torture, drew condemnation from employer bodies, individual corporate leaders, the press, academics, student leaders, and opposition members of Parliament. His death also unified and mobilised a divided labour movement against the apartheid state's labour regime. Days after his death, and in his honour, 90000 workers participated in the first national work stoppage in twenty years, including 15000 workers from his own African Food and Canning Workers' Union. A memorial service organised by the Transvaal Medical Society at Baragwanath Hospital was attended by 500 people, and 2000 people attended his funeral service in St Mary's Cathedral in Johannesburg. An estimated 15 000 people honoured his hearse as it made its way to West Park Cemetery, paying tribute not only to him, but also to his undying idealism and the ideal he died for: a democratic, non-racial, non-sexist society in which workers enjoyed wages, working and living conditions commensurate with a decent life and in which they shared in the full heritage of South Africa.

I had the privilege of meeting Beverley Naidoo when she came to Grahamstown to participate in the launch of the Neil Aggett Labour Studies Unit at Rhodes University. The value of her account of Neil's life was confirmed by former friends and comrades of Neil's who also participated - including Jan Theron, Sipho Kubeka, Gavin Andersson, Israel Mogoatlhe, Lydia Kompe, and his school friend Brian Sandberg (who passed away two weeks after the launch) - and by his sister, Jill Burger. In her account at the naming ceremony, Jill spoke of the last time she saw her brother during a visit to John Vorster Square and reminded us vividly of the deeply human tragedy of his brutal death.

The quest for justice for Neil Aggett still continues, spearheaded by the Neil Aggett Support Group, which was coordinated by Brian Sandberg until his death in 2014. Neil's principal torturer evaded testimony before the Truth and Reconciliation Commission, and made a good living as a security consultant for, amongst others, the post-apartheid government, until attention was drawn to him by Beverley's book and the activities of the Neil Aggett Support Group. Key in this quest for justice has been the successor to Neil's union, the Food and Allied Workers' Union, under the dedicated leadership of its current General Secretary, Katishi Masemola.

Death of an idealist: In search of Neil Aggett is a remarkable biography, and is recommended reading for all who are interested in broadening their understanding of South Africa under apartheid, the politics of resistance, the re-emergence of the trade union movement in the 1970s, and the complex personal histories of people engaged in these movements. Ultimately though, it brings to life the remarkable journey and societal contribution of Dr Neil Hudson Aggett, who, in the words of Oscar Mpetha, was a man of the people. 